\title{
The Hominin Sites and Paleolakes Drilling Project: inferring the environmental context of human evolution from eastern African rift lake deposits
}

A. Cohen ${ }^{1}$, C. Campisano ${ }^{2}$, R. Arrowsmith ${ }^{3}$, A. Asrat ${ }^{4}$, A. K. Behrensmeyer ${ }^{5}$, A. Deino ${ }^{6}$, C. Feibel $^{7}$, A. Hill ${ }^{8, \dagger}$, R. Johnson ${ }^{1}$, J. Kingston ${ }^{9}$, H. Lamb ${ }^{10}$, T. Lowenstein ${ }^{11}$, A. Noren ${ }^{12}$, D. Olago ${ }^{13}$, R. B. Owen ${ }^{14}$,

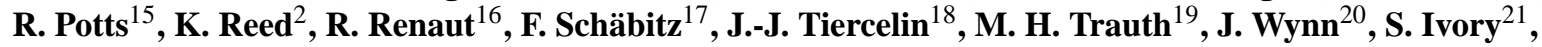
K. Brady ${ }^{12}$, R. O'Grady ${ }^{12}$, J. Rodysill ${ }^{22, a}$, J. Githiri ${ }^{23}$, J. Russell ${ }^{1}$, V. Foerster ${ }^{19}$, R. Dommain ${ }^{15}$, S. Rucina ${ }^{24}$, D. Deocampo ${ }^{25}$, J. Russell ${ }^{21}$, A. Billingsley ${ }^{1}$, C. Beck ${ }^{26}$, G. Dorenbeck ${ }^{17}$, L. Dullo ${ }^{13}$, D. Feary ${ }^{3}$, D. Garello ${ }^{2}$, R. Gromig ${ }^{27}$, T. Johnson ${ }^{28}$, A. Junginger ${ }^{29}$, M. Karanja ${ }^{13}$, E. Kimburi ${ }^{30}$, A. Mbuthia $^{31}$, T. McCartney ${ }^{32}$, E. McNulty ${ }^{11}$, V. Muiruri ${ }^{14}$, E. Nambiro ${ }^{30}$, E. W. Negash ${ }^{33}$ D. Njagi $^{13}$,

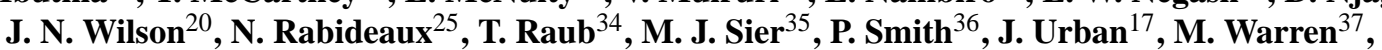
M. Yadeta ${ }^{4}$, C. Yost ${ }^{1}$, and B. Zinaye ${ }^{4}$

${ }^{1}$ Department of Geosciences, University of Arizona, Tucson, AZ 85721, USA

${ }^{2}$ Institute of Human Origins, School of Human Evolution and Social Change, Arizona State University, Tempe, AZ 85287, USA

${ }^{3}$ School of Earth and Space Exploration, Arizona State University, Tempe, AZ 85287, USA

${ }^{4}$ School of Earth Sciences, Addis Ababa University, 1176, Addis Ababa, Ethiopia

${ }^{5}$ Department of Paleobiology, National Museum of Natural History, Washington, DC 20013, USA

${ }^{6}$ Berkeley Geochronology Center, Berkeley, CA 94709, USA

${ }^{7}$ Department of Earth and Planetary Sciences, Rutgers University, Piscataway, NJ 08854, USA

${ }^{8}$ Peabody Museum, Yale University, New Haven, CT 06511, USA

${ }^{9}$ Department of Anthropology, University of Michigan, Ann Arbor, MI 48109, USA

${ }^{10}$ Institute of Geography and Earth Sciences, University of Aberystwyth, Aberystwyth SY23 3DB, UK

${ }^{11}$ Department of Geological Sciences and Environmental Studies, Binghamton University, Binghamton, NY 13902, USA

${ }^{12}$ CDSCO and LacCore, University of Minnesota, Minneapolis, MN 55455, USA

${ }^{13}$ Department of Geology, University of Nairobi, Nairobi, Kenya

${ }^{14}$ Department of Geography, Hong Kong Baptist University, Hong Kong

${ }^{15}$ Human Origins Program, National Museum of Natural History, Washington, DC 20013, USA

${ }^{16}$ Department of Geological Sciences, University of Saskatchewan, Saskatoon SK S7N 5E2, Canada

${ }^{17}$ Seminar of Physical Geography and Education, University of Cologne, 50931 Cologne, Germany

${ }^{18}$ CNRS Géosciences Rennes, Université de Rennes, 35042 Rennes, CEDEX, France

${ }^{19}$ Institute of Earth and Environmental Science, University of Potsdam, 14476 Potsdam, Germany

${ }^{20}$ School of Geosciences, University of South Florida, Tampa, FL 33620, USA

${ }^{21}$ Department of Earth, Environmental and Planetary Sciences, Brown University, Providence, RI 02912, USA

${ }^{22}$ LacCore, University of Minnesota, Minneapolis, MN 55455, USA

${ }^{23}$ Department of Physics, Jomo Kenyatta University of Agriculture and Technology, Nairobi, Kenya

${ }^{24}$ Earth Sciences Department, National Museums of Kenya, Nairobi, Kenya

${ }^{25}$ Department of Geosciences, Georgia State University, Atlanta, GA 30302, USA

${ }^{26}$ Department of Geosciences, Hamilton College, Clinton, NY 13323, USA

${ }^{27}$ Institute of Geology and Mineralogy, University of Cologne, 50674 Cologne, Germany

${ }^{28}$ Large Lakes Observatory, University of Minnesota-Duluth, Duluth, MN 55812, USA

${ }^{29}$ Senckenberg Center for Human Evolution and Palaeoenvironment, University of Tübingen, 72074 Tübingen, Germany 


\author{
${ }^{30}$ National Oil Corporation of Kenya, Nairobi, Kenya \\ ${ }^{31}$ Tata Chemicals Magadi, Magadi, Kenya \\ ${ }^{32}$ Department of Earth Sciences, Syracuse University, Syracuse, NY 13244, USA \\ ${ }^{33}$ Center for the Advanced Study of Hominid Paleobiology, George Washington University, Washington, DC \\ 20052, USA \\ ${ }^{34}$ Department of Earth Sciences, University of St. Andrews, Fife KY16 9AJ Scotland, UK \\ ${ }^{35}$ Paleomagnetics Laboratory, Department of Earth Sciences, Faculty of Geosciences, Utrecht University, 3584 \\ CD Utrecht, the Netherlands \\ ${ }^{36}$ Department of Earth and Planetary Sciences, University of New Mexico, Albuquerque, NM 87131, USA \\ ${ }^{37}$ ConocoPhillips, Houston, TX 77079, USA \\ ${ }^{\mathrm{a}}$ currently at: USGS, Reston, VA, USA \\ $\dagger$ deceased \\ Correspondence to: A. Cohen (cohen@email.arizona.edu)
}

Received: 31 October 2015 - Revised: 1 February 2016 - Accepted: 4 February 2016 - Published: 19 February 2016

\begin{abstract}
The role that climate and environmental history may have played in influencing human evolution has been the focus of considerable interest and controversy among paleoanthropologists for decades. Prior attempts to understand the environmental history side of this equation have centered around the study of outcrop sediments and fossils adjacent to where fossil hominins (ancestors or close relatives of modern humans) are found, or from the study of deep sea drill cores. However, outcrop sediments are often highly weathered and thus are unsuitable for some types of paleoclimatic records, and deep sea core records come from long distances away from the actual fossil and stone tool remains. The Hominin Sites and Paleolakes Drilling Project (HSPDP) was developed to address these issues. The project has focused its efforts on the eastern African Rift Valley, where much of the evidence for early hominins has been recovered. We have collected about $2 \mathrm{~km}$ of sediment drill core from six basins in Kenya and Ethiopia, in lake deposits immediately adjacent to important fossil hominin and archaeological sites. Collectively these cores cover in time many of the key transitions and critical intervals in human evolutionary history over the last $4 \mathrm{Ma}$, such as the earliest stone tools, the origin of our own genus Homo, and the earliest anatomically modern Homo sapiens. Here we document the initial field, physical property, and core description results of the 2012-2014 HSPDP coring campaign.
\end{abstract}

\section{Introduction}

The possibility that human evolution has been strongly influenced by changes in the Earth's environmental history, and in particular, its climate history, has been at the forefront of paleoanthropological research for the last 25 years. Few subjects captivate the public interest as much as human evolution and climate change. Today there are compelling scientific and societal needs to clarify the role of climate history in the evolution of our own species, Homo sapiens, and the evolution and extinction of our close relatives (collectively referred to as hominins). Much of the debate about human origins, from the time of the split between the hominins and the ancestors of the African great apes, about $6 \mathrm{Ma}$, has centered around the fossil record of Africa. This is where the vast majority of hominin fossils $>1 \mathrm{Ma}$ in age have been discovered, and where many important evolutionary transitions in our lineage apparently occurred, such as bipedalism, the use and increasing complexity of stone tools, and increased brain size. Within the African continent, the eastern Rift Valley has been a particularly prominent region for understand- ing human origins, as its deep tectonic basins have provided a depositional context for the accumulation of fossil hominins and other organisms, as well as a sedimentary record allowing us to both date the fossils and put them in a paleoenvironmental context.

Numerous hypotheses linking both global and regional African climate to hominin evolutionary history have been proposed. Vrba $(1985,1988,1995)$ hypothesized that Neogene mammalian (including hominin) evolution and extinction occurred in coordinated and relatively rapid turnover pulses triggered by major, directional, global environmental changes, such as the intensification of Northern Hemisphere glaciation. However, mammalian records indicate that the impact of these global mechanisms varied at local and regional levels (Alemseged, 2003; Bobe and Behrensmeyer, 2004; Bobe et al., 2007; Reed, 2008). Other major advances in understanding eastern African paleoclimate (e.g., deMenocal, 1995, 2004; Trauth et al., 2005; Scholz et al., 2007,2011 ) have spurred the development of explanatory, dynamic paleoclimate models, as well as alternative models linking paleoclimate and human evolution. Potts (1996; 
Potts and Faith, 2015) proposed that it is the variability in climate (especially at orbital forcing timescales) as opposed to simply its directional history (e.g., drying trends) that has driven large-scale evolutionary changes and technological innovations among the hominins. Unfortunately, because local outcrop paleorecords are either incomplete or discontinuous, no consensus yet exists on the factors that interacted to control African climate and ecosystem dynamics during the Plio-Pleistocene or how they affected hominin or other mammalian evolution.

On long timescales ( $>10^{6}$ years), there is debate on the timing and importance of eastern African uplift and changes in oceanic circulation as causes of climate change, and especially increasing aridity, the development of extensive grassland savanna, and their influence on the mammalian fauna (Cane and Molnar, 2001; Molnar and Cane, 2007; Sepulchre et al., 2006; Wichura et al., 2010; Cerling et al., 2011; Federov et al., 2013; Maslin et al., 2014). On intermediate timescales $\left(10^{4}-10^{6}\right.$ years $)$, there is controversy regarding the relative importance of high-latitude glacial cycles, Walker circulation intensification, and annual- to decadalscale variability in atmospheric pressure and sea surface temperatures such as El Niño-Southern Oscillation and the Indian Ocean Dipole (ENSO/IOD) for regional aridity, lake expansions, and seasonality (deMenocal, 2004; Trauth et al., 2009), all of which could have influenced the course of evolution in the lake-rich Rift Valley. On Milankovitch $(\sim 100$, 40 , and $20 \mathrm{kyr})$ and shorter $\left(10^{1}-10^{4}\right.$ years) timescales, there is debate about the role of orbital forcing and high-latitude glacial to millennial-scale events in driving wet-dry cycles that increased environmental pressures on African ecosystems (e.g., Larasoaña et al., 2003; Kingston et al., 2007; Scholz et al., 2007; Campisano and Feibel, 2007; Trauth et al., 2009, 2015; Armitage et al., 2011; Blome et al., 2012), and how these might have influenced resource acquisition (Reed and Rector, 2007) and other ecological parameters affecting hominins. Assessing these hypotheses is complicated by the need to understand the role of biotic drivers of adaptation, such as competition and predation. One fundamental question is whether any of the Earth system drivers can be characterized with sufficient precision to identify drivers of diversification and extinction among our close relatives and ancestors and to enable correlation with hominin evolution.

Past attempts to test hypotheses that implicate climate as a major driver of human evolution have often foundered on a fundamental mismatch of spatial and temporal scales, casting highly temporally resolved, but globally or continentally spatially averaged records of climate change against less temporally resolved but basin-scale records of faunal change and/or hominin evolution. This approach cannot yield a realistic understanding of potential linkages between environmental and biotic change, because it ignores basin-scale environmental dynamics relating to changes in regional climate, that is, local tectonics and geomorphology, which could also be drivers of mammalian population dynamics. For example, Behrens- meyer et al. (1997) tested Vrba's turnover pulse hypothesis by investigating whether such a pulse occurred in changing mammal communities at $2.8 \mathrm{Ma}$ in the Turkana Basin of northern Kenya, a region with a rich and highly continuous fossil record. They found that species patterns in the Turkana Basin did not follow this global model, and that species turnovers were more prolonged responses to climate change associated with both drier and more variable climatic conditions. Tectonic forcing (Bailey et al., 2011) and extreme environmental perturbations, such as megadroughts (Cohen et al., 2007; Scholz et al., 2007), have also been suggested as potential drivers of early modern human population fragmentation, genetic differentiation, range expansion events, and adaptation (Mellars, 2006). The implications of millennial-scale or even shorter events for early hominin evolution have scarcely been explored as they are poorly resolved in offshore marine records. However, such events were clearly linked to major demographic and population-level changes during the Holocene in Africa (e.g., Kuper and Kröpelin, 2006).

Current hypotheses remain difficult to test and there has been an acute need to develop new perspectives and data on the links between global- and basin-scale environmental change, and to relate these specific changes to ecological factors that influenced hominin evolution. The Hominin Sites and Paleolakes Drilling Project (HSPDP) was designed to improve understanding of the implications of ecosystem change for hominins in two ways: (1) to provide millennialscale environmental data at key time periods that correspond to morphological and cultural changes or other perceptible evolutionary events in hominin and other mammalian lineages near locations where hominin fossils have been found, and (2) to compare these data across basins, encompassing multiple paleoanthropological localities, to document local versus regional effects of ecosystem change, and responses to global-scale changes. For the specific case of hominin and large mammal evolution in Africa, in order for a paleoenvironmental record to be useful for improving our understanding of the connection between evolution and climate, it must meet two conditions.

1. There must be a highly resolved paleorecord to examine environmental change at any temporal scale that could realistically serve as an evolutionary or ecological trigger. This would range from annual records of seasonality preserved in archives such as annual lake deposits, pollen records of plants responsive to variable seasonality, lipid markers of temperature, etc. to geochemical or sedimentological records of phenomena such as major uplift or paleoceanographic events, which might operate on much longer (e.g., $>10^{6}$ years) timescales.

2. A record of faunal change from the same localities that is sufficiently detailed to investigate responses to environmental change within particular clades, ecological guilds, or mammal communities. 
The HSPDP was developed by an international team of over 100 scientists from 11 countries to address these issues. Its goal was the collection and analysis of high-resolution paleoenvironmental records from paleo-lake drill cores near the depocenters of lacustrine basins of significant paleoanthropological importance in eastern Africa, each of which meets these conditions. As discontinuously exposed outcrops have shown these lakebeds to be commonly laminated (e.g., Wilson et al., 2014) with bedding characteristics often similar to demonstrably annual varves documented in modern African rift lakes (Pilskaln and Johnson, 1991; Cohen et al., 2006) and deposited at high sedimentation rates, their records fulfill the first criterion. The second criterion is fulfilled as each of the drill sites lies in close proximity to rich and diverse fossil vertebrate and archaeological sites, with sediments of the same age, and which collectively span some of the most critical intervals of hominin evolutionary history (e.g., earliest Homo, earliest stone tools, origin of Acheulian and Middle Stone Age technologies, earliest modern H. sapiens), and where new, important fossils and artifacts are still being recovered. Thus, the integration and direct comparison of basin-scale records of environmental change from cores with the record of faunal and cultural change from outcrops affords us the opportunity to test existing hypotheses of Earth system drivers of evolution at different temporal and spatial scales.

\section{Drilling target areas}

A series of workshops held in the mid-late 2000s better defined the specific goals of the HSPDP and specific selection criteria for ideal drilling locations (Cohen and Umer, 2009; Cohen et al., 2009). The drilling areas (Table 1 and Fig. 1) were decided through a lengthy and interactive process between the principal ICDP project proponents. Numerous hominin fossil and archaeological sites in proximity to lake deposits in eastern Africa were considered as potential drilling targets, and ultimately the decision on which sites to pursue was determined by a combination of the scientific criteria mentioned above, along with practical, logistical considerations, such as site access for a truck-mounted drill rig and probable costs. The sites discussed below were part of the original HSPDP operational plan. The Olorgesailie (Koora Plain) site was ultimately funded separately from the remaining ICDP-supported sites.

\subsection{The Northern Awash drilling area, Ethiopia}

The Northern Awash basin provides one of the densest accumulations of early hominin fossils (Johanson et al., 1982; Kimbel et al., 2004; Alemseged et al., 2006), as well as rich mammalian faunal and floral records (Bonnefille et al., 2004; Reed, 2008; Geraads et al., 2012). Its lakebeds provide a potential record of the local environmental response to the onset of high-amplitude climate oscillations and increased aridity

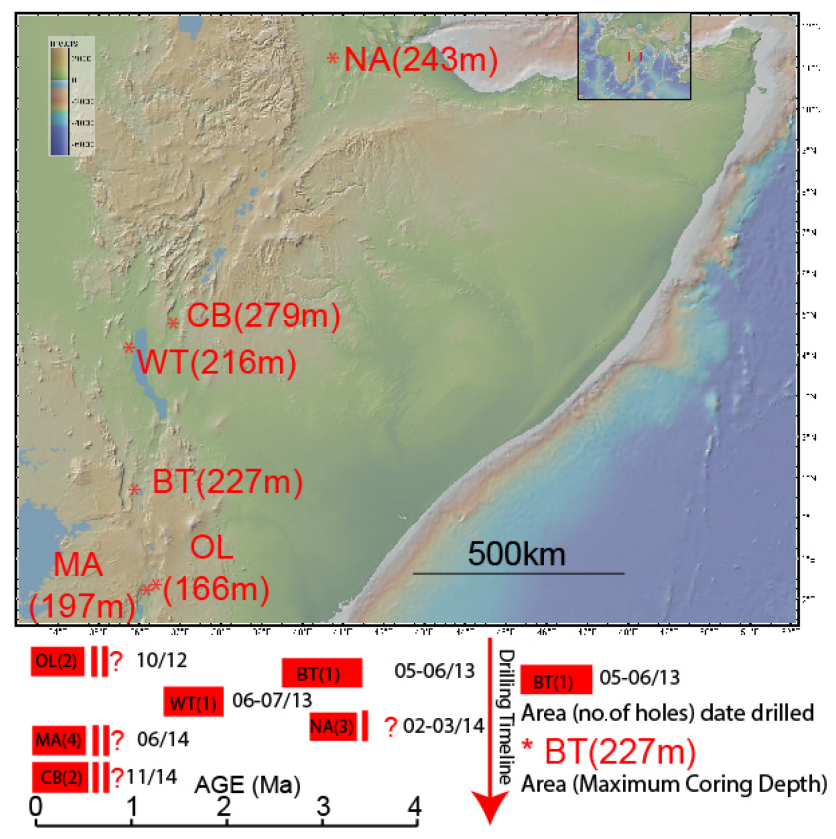

Figure 1. Map of eastern Africa showing locations of the HSPDP drilling areas; maximum coring depth for the deepest borehole in red on the map (the BT $(227 \mathrm{~m})$ example indicates the maximum depth, $227 \mathrm{~m}$, that was reached at the BT site). The timeline below the map shows the number of cored boreholes, drilling dates, and approximate time intervals covered by the drill cores from each area. From north to south: NA: Northern Awash; CB: Chew Bahir; WT: West Turkana; BT: Baringo Tugen Hills; OL: Olorgesailie/Koora Plain; and MA: Lake Magadi. Base map generated from GeoMapApp ${ }^{\circledR}$.

in eastern Africa at $\sim 3.15 \mathrm{Ma}$ as well as the response to $\mathrm{Mi}$ lankovitch cycles prior to the onset of high-latitude glaciation $(\sim 2.7 \mathrm{Ma})$ as documented in the marine core record (Campisano and Feibel, 2007). This site provides a backdrop against which $\sim 400 \mathrm{kyr}$ of the evolutionary history of Australopithecus afarensis (e.g., "Lucy") and associated fauna and the earliest use of stone tools (McPherron et al., 2010) will be interpreted.

\subsection{The Baringo Basin/Tugen Hills drilling area, Kenya}

This area of the central Kenyan Rift Valley comprises the most complete late Neogene section known from the African rift (Chapman and Brook, 1978). The stratigraphic interval of the Chemeron Formation targeted here (3.3-2.6 Ma) contains $\sim 100$ fossil vertebrate localities, including three hominin sites, providing an opportunity to explore the nature of environmental change associated with shifting insolation patterns (for example, documenting the lacustrine response to changing precipitation patterns at precessional, millennial, and perhaps even shorter timescales; e.g., Kingston et al., 2007; Wilson et al., 2014) and to assess specific terrestrial community responses to pervasive, short-term climatic 
Table 1. Borehole site information for the HSPDP. DA: drilling area; age: approximate age range of borehole sediments; NA: Northern Awash, Ethiopia; BTB: Baringo/Tugen Hills, Kenya; WTK: West Turkana, Kenya; SK: southern Kenya; KO: Koora Plain/Olorgesailie; MAG: Lake Magadi; CHB: Chew Bahir, Ethiopia; ID: borehole identification number; SD: spud date; LAT: latitude N (-: S); LONG.: longitude E; BE: borehole surface elevation in meters above sea level; BI: borehole inclination in degrees off vertical; BT: borehole top depth in meters to top of cored interval from surface; DL: drilled length in meters; CL: cored length in meters; CR: total core recovered in meters; CR: percentage core recovery; LOG: downhole logging type; NG: natural gamma (U, Th, K); MS: magnetic susceptibility; R: resistivity; T: temperature. For MAG14-2A, MS was collected from 4 to $14 \mathrm{~m}$ and 82 to $197 \mathrm{~m}$ only, R from 4.5 to $12.5 \mathrm{~m}$ and 82.5 to $139 \mathrm{~m}, 143$ to $161 \mathrm{~m}$ and 165 to $197 \mathrm{~m}$ only, and MS from 82 to $197 \mathrm{~m}$ only. For OLO12-1A the hole was reverse-circulation drilled down to $27 \mathrm{~m}$ with cuttings bagged from 0 to $27 \mathrm{~m}$. For OLO12-2A, borehole was reamed to find bedrock depth (encountered at $159 \mathrm{~m}$ ). No coring attempted.

\begin{tabular}{|c|c|c|c|c|c|c|c|c|c|c|c|c|}
\hline \multicolumn{13}{|l|}{ NA (Late Pliocene) } \\
\hline & HSPDP-NAO14-1A & $23 / 2 / 2014$ & 11.315 & 40.7369 & 520 & 15 & 1.84 & 4.84 & 4.84 & 2.6 & 53.7 & None \\
\hline & HSPDP-NAO14-1B & $23 / 2 / 2014$ & 11.315 & 40.7369 & 520 & 13 & 1.29 & 187.4 & 187 & 205.4 & 110 & None \\
\hline & HSPDP-NAO14-1C & $28 / 2 / 2014$ & 11.315 & 40.737 & 521 & 13 & 0 & 3 & 3 & 2.67 & 88.8 & None \\
\hline & HSPDP-NAO14-1D & $1 / 3 / 2014$ & 11.315 & 40.737 & 521 & 14 & 0 & 168.4 & 167 & 181.9 & 109 & None \\
\hline & HSPDP-NAO14-1E & $4 / 3 / 2014$ & 11.315 & 40.7649 & 521 & 13 & 172.7 & 0 & 0 & 0 & 0 & None \\
\hline & HSPDP-NAW14-1A & $11 / 3 / 2014$ & 11.325 & 40.7649 & 495 & 12 & 0 & 244.5 & 245 & 254.6 & 104 & None \\
\hline \multicolumn{13}{|c|}{$\begin{array}{l}\text { BTB (Late Pliocene-Early } \\
\text { Pleistocene) }\end{array}$} \\
\hline & HSPDP-BTB13-1A & $1 / 6 / 2013$ & 0.5546 & 35.9375 & 1158 & 0 & 5.25 & 227.9 & 223 & 210 & 94.3 & $\begin{array}{l}\text { NG, MS, } \\
\mathrm{R}, \mathrm{T}\end{array}$ \\
\hline \multicolumn{13}{|c|}{ WTK (Early Pleistocene) } \\
\hline & HSPDP-WTK13-1A & $22 / 6 / 2013$ & 4.1097 & 35.8718 & 404 & 10 & 0.55 & 215.8 & 215 & 202.6 & 94.1 & $\mathrm{NG}, \mathrm{T}$ \\
\hline \multicolumn{13}{|c|}{ SK (Middle Pleistocene-Holocene) } \\
\hline \multicolumn{13}{|l|}{ OL } \\
\hline & ODP-OLO12-1A & $5 / 9 / 2012$ & -1.791 & 36.4011 & 862 & 0 & 27 & 166.1 & 139 & 130.8 & 94 & None \\
\hline & ODP-OLO12-2A & $17 / 9 / 2012$ & -1.7887 & 36.3968 & 862 & 0 & & 159 & 0 & 0 & 0 & None \\
\hline & ODP-OLO12-3A & $21 / 9 / 2012$ & -1.7887 & 36.4085 & 852 & 0 & 50 & 116.3 & 66.3 & 66.73 & 101 & None \\
\hline \multicolumn{13}{|l|}{ MAG } \\
\hline & HSPDP-MAG14-1A & $11 / 6 / 2014$ & -1.8805 & 36.2717 & 607 & 0 & 3.02 & 128.5 & 126 & 74.51 & 59.2 & None \\
\hline & HSPDP-MAG14-1B & $23 / 6 / 2014$ & -1.8806 & 36.2717 & 607 & 0 & 119.64 & 125.7 & 6.1 & 2.87 & 47 & None \\
\hline & HSPDP-MAG14-1C & $25 / 06 / 2014$ & -1.8806 & 36.2717 & 607 & 0 & 3.44 & 136.6 & 26.5 & 16.84 & 63.6 & None \\
\hline & HSPDP-MAG14-2A & $29 / 06 / 2014$ & -1.8516 & 36.2794 & 607 & 0 & 3 & 197.4 & 194 & 107.7 & 55.4 & $\begin{array}{l}\text { NG, MS, } \\
\text { R, MS }\end{array}$ \\
\hline \multicolumn{13}{|c|}{ CB (Middle-Late Pleistocene) } \\
\hline & HSPDP-CHB14-1A & $18 / 03 / 14$ & 4.4225 & 36.5109 & 500 & 0 & 0 & 41.5 & 39.1 & 39.05 & 94 & None \\
\hline & HSPDP-CHB14-2A & $6 / 11 / 2014$ & 4.7612 & 36.7668 & 500 & 0 & 0.49 & 278.6 & 284 & 245.4 & 86.6 & None \\
\hline & HSPDP-CHB14-2B & $19 / 11 / 2014$ & 4.7613 & 36.767 & 500 & 0 & 0.28 & 266.4 & 266 & 240.9 & 90.5 & None \\
\hline Totals & & & & & & & & 2668 & 2192 & 1985 & 90.6 & \\
\hline
\end{tabular}

change through the interval of Northern Hemisphere glacial intensification. At this time in eastern Africa we also observe the diversification of Paranthropus (a group of hominins with robust cranial features and large teeth for a strong bite force) and our own genus Homo, as well as the earliest evidence for stone tool-making in nearby West Turkana (Harmand et al., 2015).

\subsection{The West Turkana drilling area, Kenya}

This area targets the Early Pleistocene lakebeds of Turkana, Kenya, that were deposited during a phase of overall increasing continental aridity punctuated by major lake-level fluctuations, which appear to reflect insolation-forced climate cycles (Lepre et al., 2007; Joordens et al., 2011). The extensive outcrops of the Turkana Basin have been well character- ized geologically (Feibel, 2011) and have provided an unparalleled tephrostratigraphic framework (Brown et al., 2006) associated with precise chronostratigraphic controls (McDougall et al., 2012). This borehole is in direct proximity to the rich fossil record of the Turkana Basin, including $\sim 500$ hominin fossils and more than 100 archaeological sites (Harris et al., 1988; Roche et al., 2004). The hominins include significant specimens, such as the earliest/most complete specimens of $H$. rudolfensis and $H$. erectus, early members of our own genus. The time window targeted here $(\sim 1.9-1.4 \mathrm{Ma})$ also includes the earliest evidence of Acheulean (e.g., large hand axes) stone tool technology (Lepre et al., 2011) and the interval when hominins first expanded their range outside of Africa. The core record will allow us to explore whether (and which) climate drivers caused the expansion of grassland habitats in the early Pleistocene in this region, what climatic 
conditions/changes were associated with the first appearance of early Homo (H. habilis/rudolfensis) and the emergence of $H$. erectus, and what were the temporal links between climate change, the episode of major faunal turnover (i.e., the near-wholesale replacement of one set of species by another), grassland expansion, and the appearance of $H$. erectus, all occurring shortly after $2 \mathrm{Ma}$ in the Turkana Basin.

\subsection{The southern Kenya (Olorgesailie and Lake Magadi) drilling areas}

These drill sites comprise contemporaneous Early Pleistocene to modern records from two adjacent (but hydrologically distinct) basins. Drill cores from these localities in the southern Kenya rift may provide a regional equatorial paleoclimate history of the major Middle-Late Pleistocene climate transitions, which is otherwise recorded from this region in only discontinuous records. Drilling on the Koora Plain will allow us to examine deposits immediately adjacent to the Olorgesailie depositional basin, one of the richest, bestcalibrated Early-Late Pleistocene archeological localities in Africa, with abundant Acheulean and Middle Stone Age (MSA) sites (and documenting the transition between these important technological phases of human prehistory), diverse fauna, a detailed paleoenvironmental record, and abundant tephras (e.g., Potts et al., 1999; Sikes et al., 1999; Behrensmeyer et al., 2002; Owen et al., 2008). Prior research here has fueled hypotheses and debates about climate-evolution relationships (e.g., Owen et al., 2009a, b; Trauth and Maslin, 2009).

Nearby Lake Magadi ( $~ 20 \mathrm{~km}$ from the Koora Plain drill site) is located in the axis of the southern Kenya Rift and is a regional sump for water and sediments. The present lake, a saline/alkaline pan, is the successor to a series of paleolakes that have occupied the basin since the Early Pleistocene. Previous outcrop and drill core records (none of which survive) established the volcanic and sediment stratigraphy and their linkage to basin hydrology (Baker, 1958; Surdam and Eugster, 1976; Crossley, 1979; Eugster, 1980; Jones et al., 1977). The close proximity of both basins will provide us with an opportunity to tease out climatic from tectonic/groundwater controls on their respective environmental histories, contributing to HSPDP Objective 2 - the evaluation of how global climate changes were experienced locally within key hominin locales.

\subsection{The Chew Bahir drilling area, Ethiopia}

This area comprises Middle-Late Pleistocene lakebeds in a region between the Ethiopian and Omo-Turkana rifts, each of which has a highly distinctive Quaternary biogeographic history (Suwa et al., 2003) and border presumed habitat refuge areas during times of climatic stress (Foerster et al., 2015). Chew Bahir is an ephemeral playa today, but in the past has held a large lake (Foerster et al., 2012). Our records from
Chew Bahir, presumed to cover at least the last $700 \mathrm{kyr}$, will also provide a regional-scale environmental context for the earliest anatomically modern $H$. sapiens fossils recovered at $\sim 200 \mathrm{ka}$ in the nearby (90 km away) Omo River valley (Day, 1969; McDougall et al., 2005; Brown et al., 2006). When coupled with the other Early Pleistocene-recent HSPDP records from Olorgesailie and Magadi and previously collected drill core records from Lake Malawi and elsewhere in the region, the details of regional environmental heterogeneity in eastern Africa through the extreme climatic fluctuations of the Quaternary may be explored (e.g., Blome et al., 2012).

\section{Pre-drilling site surveys}

Between 2008 and 2012 subsurface and outcrop site survey data were collected in a series of campaigns from all of the drill sites to determine optimal locations for the various boreholes. The objective was to minimize the likelihood of encountering subsurface faults or associated deformation and to maximize stratigraphic resolution. Seismic data were acquired by our group at the Afar, West Turkana and Olorgesailie areas. Additionally, legacy industry seismic data were obtained from an old (1970s) AMOCO survey at West Turkana and very recently acquired survey data from Tullow Oil at the Chew Bahir area. Gravity and magnetic surveys were also conducted by our team at the Magadi and Olorgesailie areas. Prior boreholes drilled by the US Geological Survey in the late 1960s at Lake Magadi provided additional information for that area. Siting at the Baringo Basin/Tugen Hills was based on known outcrop exposures immediately adjacent to the drill site.

\section{Drilling and logging operations (Figs. 2 and 3)}

Drilling of the HSPDP sites took place over an approximately 2-year period between September 2012 and December 2014. Local drilling contractors, Drilling and Prospecting International for Kenya areas, Addis GeoSystems for the Chew Bahir pilot hole, and Geosearch (now Orezone Drilling) for all other holes in Ethiopia, provided truck-mounted standard wireline diamond coring drill rigs and crews. DOSECC Exploration Services (DES) provided drilling operations oversight, local supervision and specialized lake tools, bits, and other drilling supply procurement for items that were not locally available. Boreholes were drilled using a combination of $\mathrm{H}$ (96.3 mm diameter hole, $61.1 \mathrm{~mm}$ diameter core), $\mathrm{P}$ (122.6 mm hole, $66 \mathrm{~mm}$ core), and minor $\mathrm{N}$ (75.7 $\mathrm{mm}$ hole, $47.6 \mathrm{~mm}$ core, at Awash) diameter drill string and a variety of coring tools depending on the highly variable lithologic conditions encountered during drilling. $\mathrm{P}$ was employed when using the specialized lake coring tools in unconsolidated sediments. These included the hydraulic piston corer, the "extended nose" non-rotating corer, "alien" rotating corer, all using standard IODP butyrate core liners. Boreholes were 


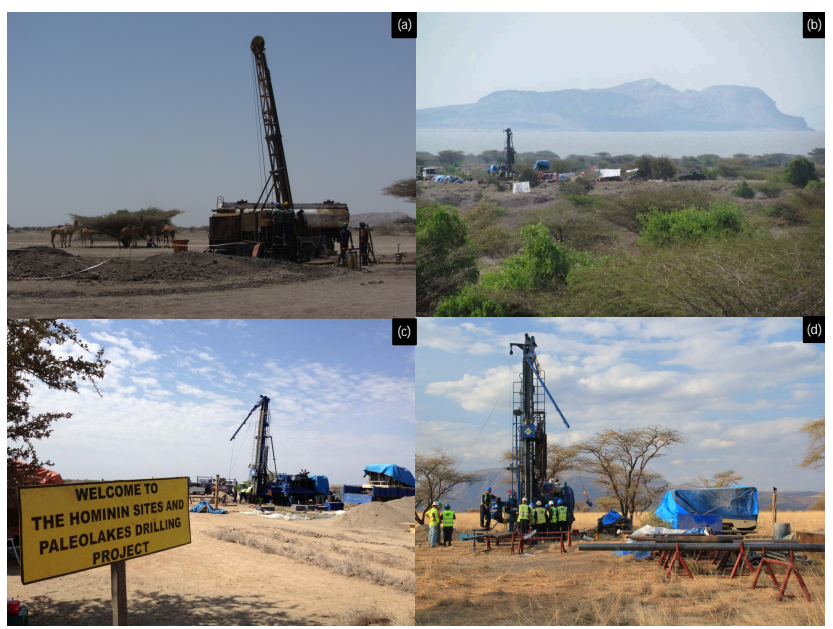

Figure 2. HSPDP drilling operations: (a) Oso Isi drill site (NAO14) in the Northern Awash area, northern Ethiopia (photo C. Campisano); (b) West Turkana (WTK13) drill site, with Lake Turkana and North Island in the background (photo A. Cohen); (c) West Turkana drill site (photo A. Noren); (d) Koora Plain/Olorgesailie (OLO121A drill site with Mt. Olorgesailie in the background (photo R. Dommain).

oriented at $10-15^{\circ}$ off the vertical at the Northern Awash and West Turkana sites to facilitate the interpretation of paleomagnetic data sets. At the Tugen Hills site, the existing $\sim 20^{\circ}$ dip of sediments at the borehole site allowed us to drill vertically. At the three remaining sites (Magadi, Olorgesailie, and Chew Bahir) the presence of unconsolidated sediments made drilling at a non-vertical angle impractical, because the risk of cave-ins and losing hole integrity was deemed to outweigh the advantages for the paleomagnetic data interpretation. A Reflex ACT III orientation device was deployed with each drive at the West Turkana and Northern Awash sites to determine azimuthal data on non-vertical boreholes. Geophysical down-hole logging data were collected by ICDP's Operational Support Group for natural gamma, magnetic susceptibility (MS), resistivity, borehole temperature and azimuthal direction at three of the Kenyan sites (Tugen Hills/Baringo, West Turkana and Lake Magadi). Logging was limited at the West Turkana borehole because of lost casing remaining in the hole at the time of logging. No down-hole logging was conducted at the remaining sites due to unforeseen circumstances. A multisensor core logger (MSCL, Geotek Ltd.) was deployed to the Tugen Hills/Baringo and West Turkana sites to collect MS data on unsplit cores during drilling, but the MSCL was not available for the remaining sites.

After drilling each site, cores were shipped via airfreight to LacCore, the National Lacustrine Core Facility (University of Minnesota) for full scanning, processing, description, and subsampling. Physical properties for cores from all sites were analyzed in detail via MSCL-S (whole core, for $p$ wave velocity, gamma density, loop MS, non-contact electrical resis-

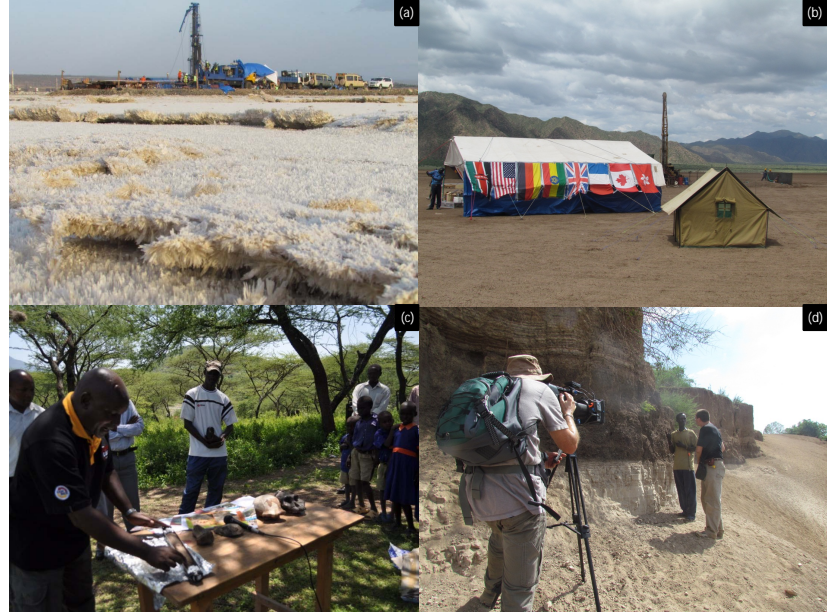

Figure 3. HSPDP drilling operations: (a) Lake Magadi drill site (MAG14) in the southern Kenya Rift Valley. Crystalline trona on the dry Magadi pan visible in the foreground (photo A. Cohen); (b) Chew Bahir drill site (CHB14) in the southern Ethiopian Rift Valley, Hammar Range in the background (photo A. Cohen); (c) HSPDP presentation to the local community group by National Museums of Kenya personnel at the Tugen Hills drill site (photo courtesy of National Museums of Kenya); (d) filmmaker Doug Prose of Earth Images Foundation filming tephra outcrops in the Omo River Valley, near the Chew Bahir drill site (photo A. Cohen).

tivity, natural gamma radiation) and MSCL-XYZ (split core, for high-resolution MS and color reflectance spectrophotometry) at increments ranging from 0.5 to $4 \mathrm{~cm}$, depending on the parameter. Cores were split in half lengthwise, cleaned, and scanned with a Geotek ${ }^{\odot}$ MSCL-CIS digital linescan core imager. Visual core description, smear slide analysis, and (as needed) SEM-EDS and XRD analyses were performed, and subsamples were extracted according to coordinated plans for stratigraphically equivalent samples for all analytical parameters.

\section{Initial coring and core description results}

In total, 18 boreholes were drilled in the HSPDP (Table 1), although several of these were "deadman" anchoring holes to secure the drill rig and not intended for core recovery. Approximately $2 \mathrm{~km}$ of core was recovered from about $2200 \mathrm{~m}$ of cored intervals, for an average recovery of $\sim 90.5 \%$. The only area where recovery was significantly below this average was at the Lake Magadi site, where interbedded hard and soft lithologies (cherts and unconsolidated muds) made for extremely challenging coring conditions.

Six boreholes were drilled at the Northern Awash area from two sites (NAO/Osi Isi and NAW/Woranso, Fig. 2a), which yielded approximately $650 \mathrm{~m}$ of core. The longest single borehole was $\sim 244 \mathrm{~m}$ (NAW-1A), but, because of the offset between the stratigraphically higher top of NAO (about $25 \mathrm{~m}$ above the top of NAW) we estimate the total strati- 


\section{Key to all lithologic symbols}

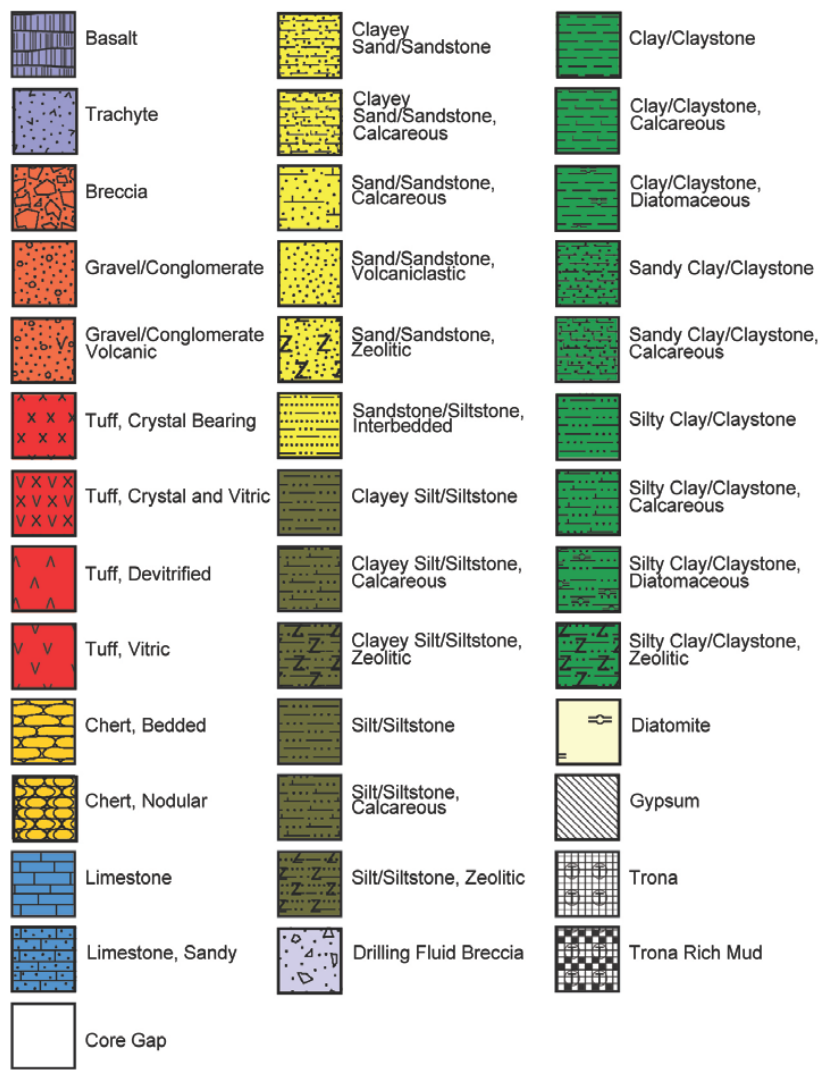

Figure 4. Key to all lithologic symbols. Note that blank (white) areas in lithologic columns indicate zones of missing core, i.e., no core recovery.

graphic interval covered by the two sites to be approximately $270 \mathrm{~m}$. Boreholes consisted of three primary science boreholes inclined $13-15^{\circ}$, plus two cored anchoring holes and one uncored hole, all of which were drilled in FebruaryMarch 2014. Thick basalt sections were encountered at both sites (some of which appear to be compound flows), which are separated by about $3 \mathrm{~km}$. Sediments at both drill sites are gently dipping $\left(\sim 2^{\circ} \mathrm{NE}\right)$. The two longest cores (NAO-1B, Fig. 5 and NAW-1A, Fig. 6) consist of primarily massive or laminated, brown or greenish brown silty clays, with occasional sandy units scattered through the core, particularly associated with the upper basalt (Fig. 7a, b). Diatomites occur sporadically, mostly in the upper portions of both cores, with diatomaceous units more abundant below the second basalt. Thin $(\mathrm{mm}-\mathrm{cm})$ unaltered airfall volcanic ashes occur throughout the core. Most of the pronounced low-MS and low gamma density zones consist of either diatomites or fine, greenish clays. The brown clays contain abundant paleosol nodules and occasional beds of gastropods. Drilling at both the NAO and NAW localities was terminated when advancing the holes became impractical as rods became stuck
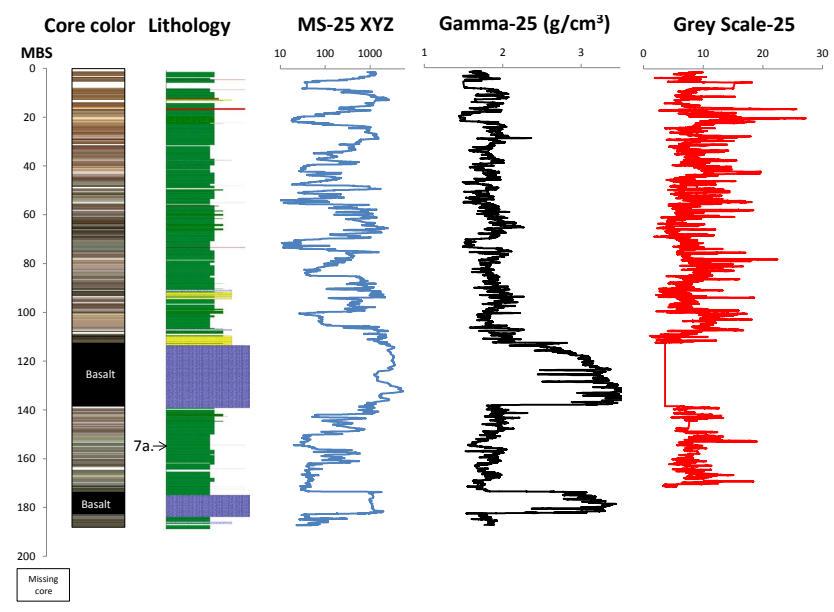

Figure 5. Summary stratigraphy of core HSPDP-NAO14-1B, from the Oso Isi locality, Northern Awash drilling area, northern Ethiopia, based on initial core description results. Columns from left to right: core color stratigraphy (from XYZ spectrophotometric imaging data, adjusted in Photoshop ${ }^{\circledR}$ to using Image Adjustment Levels to maximize color range). Basalt intervals were not imaged and are shown as solid black and missing core intervals are shown in white; lithologic log, rendered in PSICAT ${ }^{\odot}$. See Fig. 5 for the key to lithologies used in all cores illustrated. Zones with missing cores are indicated by blank intervals. Letter/number markers and arrows to the left of the lithologic log indicate the position of corresponding core photos in Fig. 7 for this and other summary stratigraphy figures; composite of magnetic susceptibility (MS) log data from the LacCore Geotek $^{\circledR}$ XYZ point sensor data on split core segments, measured at $0.5 \mathrm{~cm}$ increments. Data have been smoothed (25-point running mean smooth, hence MS-25, Gamma-25, and Grey Scale-25); composite of induced gamma density log data at $0.5 \mathrm{~cm}$ increments from the LacCore Geotek ${ }^{\circledR}$ Multisensor Core Logger (MSCL). Spurious values $\left(<1.4 \mathrm{gm} \mathrm{cm}^{-3}\right)$ caused by coring gaps have been removed prior to analysis and plotting. Data have been smoothed (25-point running mean); composite of spectrophotometric grey-scale $\log$ data at $0.5 \mathrm{~cm}$ increments from the LacCore Geotek ${ }^{\circledR}$ XYZ spectrophotometric sensor. Data have been smoothed (25-point running mean).

because of very tight hole conditions, very high torque, and water pressure.

A single, vertical $\sim 228 \mathrm{~m}$ borehole was drilled at the Tugen Hills site in May-June 2013 (Fig. 8). The borehole was situated in very close proximity to exposures of variably dipping (20-42 ${ }^{\circ}$ in the borehole) cyclic diatomites and mudstones of the upper Chemeron Formation, which had previously been shown by Deino et al. (2006) and Kingston et al. (2007) to reflect extreme precessional climate variability in the central Kenyan Rift during the Plio-Pleistocene transition. The lower $\sim 100 \mathrm{~m}$ of the core is coarser on average than the upper part of the core. From the base to $\sim 130 \mathrm{~m} \mathrm{b.s.}$ the core contains frequent channelized granular sands and conglomerate beds (often reddish in color), alternating with carbonate nodular paleosol siltstones (Fig. 7c), with sparse 


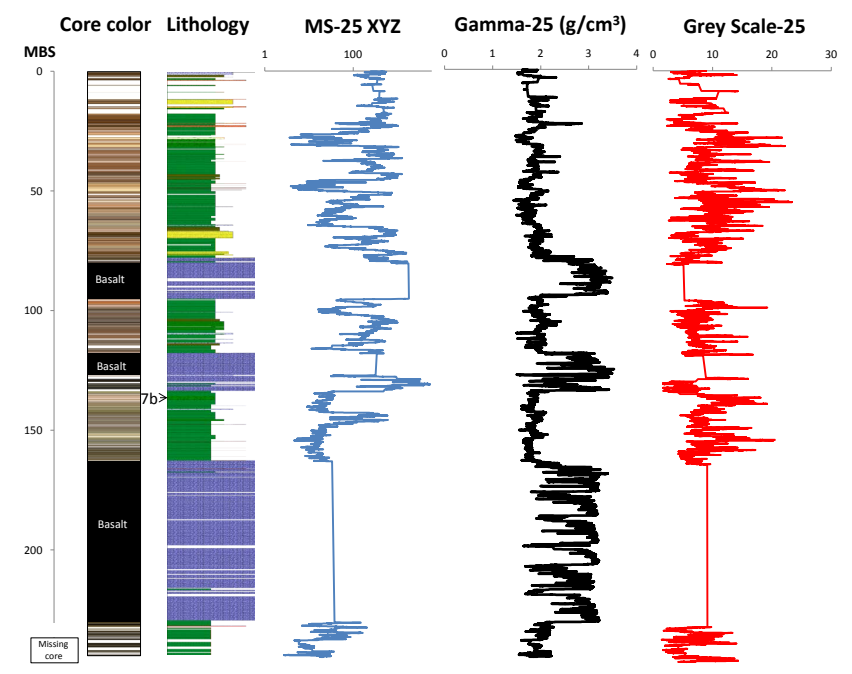

Figure 6. Summary stratigraphy of core HSPDP-NAW14-1A, from the Woranso locality, Northern Awash drilling area, northern Ethiopia, based on initial core description results. Columns from left to right: core color stratigraphy; lithologic log; see Fig. 5 for the key to lithologies used in all cores illustrated; composite of magnetic susceptibility (MS) log data (25-point running mean smooth) from LacCore Geotek ${ }^{\circledR}$ XYZ point sensor data; composite of induced gamma density log data (25-point running mean smooth, spurious values $<1.4 \mathrm{gm} \mathrm{cm}^{-3}$ removed); composite of spectrophotometric grey-scale log data (25-point running mean smooth). All data collection, instrumentation, and parameters as in Fig. 5.

lacustrine muds and diatomites. Above this, diatomite lacustrine/terrestrial cycles similar to those seen in outcrop begin to appear (evident in both the lithologies and physical properties of the upper portion of the drill core, Fig. 7d). Lowdensity, low-magnetic-susceptibility sediments (light colored lacustrine diatomites and clays) alternate with more strongly magnetically susceptible and denser siliciclastic muds (paleosols, often with abundant carbonate nodules) and fluvial sands (and occasional gravels) in the upper $130 \mathrm{~m}$ of the core. Sediments above $\sim 50 \mathrm{mb}$ b.s. are generally lighter in color (note grey-scale data, Fig. 8), which may reflect near-surface weathering/alteration above the local water table. Numerous primary and reworked tephras occur throughout the core, which will be critical for dating the core. Drilling was terminated at this site close to the original planned target depth $(250 \mathrm{~m})$ for budgetary reasons.

A single, oriented $\left(10^{\circ}\right.$ from vertical $) \sim 216 \mathrm{~m}$ borehole was drilled at the West Turkana (WTK) site in June-July 2013 (Figs. 2c, d and 9). The drill site was chosen to be in close proximity to outcrop exposures of the correlative Nachukui Formation, which is locally dipping at $\sim 5^{\circ} \mathrm{W}$. The lower $\sim 155 \mathrm{~m}(61-216 \mathrm{~m}$ b.s.) of the core consists of laminated to massive green and brown clays, which are often fossiliferous (fish, ostracodes and molluscs, the latter often organized as discrete shell lags) (Fig. 7e). Many of these lacustrine clays contain paleosol structure and carbonate nod- ules indicative of episodic exposure and pedogenesis. Above $61 \mathrm{mb}$ b.s., a pronounced lithologic transition occurs towards coarser sediments (more frequent sandy intervals), which is also reflected in changes in the color and magnetic susceptibility of the core. Soil structure and nodular carbonates occur in these sediments as well. Tuffs occur as discrete horizons at several depths within the core, which at this locality will be critical for tephrostratigraphic correlation with nearby outcrops. Drilling was terminated at this site when borehole instability, high torque, and high-pressure groundwater caused an inability for the drilling to advance. Bottom hole temperatures also began to rise abruptly near the base of the hole, indicating a potential hydrothermal hazard.

Three vertical boreholes were drilled (and two cored) at the northern end of the Koora Plain, in the southern Kenya Rift Valley, $\sim 22 \mathrm{~km} \mathrm{SSW}$ of the Olorgesailie archaeological site in September-October 2012 (Figs. 2d, 10, and 11). Because the DOSECC soft sediment tools were not available at this time, the upper, unconsolidated sediments of both boreholes were auger drilled and cuttings were bagged at Site 1. Excellent core recovery was achieved at both sites below the augered intervals (Table 1 and Figs. 10 and 11). Both cores consist of flat-lying, interbedded muds (laminated in part), diatomites, and fine to coarse sands, with some pumice-rich gravel and conglomerate intervals and infrequent carbonate marls as well. Numerous tuffs are also present. Both cores bottomed in the trachyte basement that underlies the basin at depths of $\sim 166$ and $116 \mathrm{~m}$ for Sites 1 and 3, respectively.

Four vertical boreholes at two sites were drilled into flatlying sediments at Lake Magadi in June 2014, and downhole logs were made in the single borehole at Site 2 (Figs. 3a, $12,13)$. Unlike other sites, it was necessary to drill from a raised pad at Lake Magadi, because the surface trona crust was inundated and soft from recent rains. A custom-built pad was constructed by the project for Site 1 adjacent to the main causeway crossing the lake, whereas Site 2 took advantage of a wide area along another existing elevated roadbed on the playa. Also in contrast to the other drilling targets, the Lake Magadi sediments consist of large proportions of trona (Fig. 7f) and other Na carbonates and chert (Fig. 7g, as well as both laminated (Fig. 7h) and massive lacustrine muds. Muds, mudstones, and cherts in varying proportions dominate the lower stratigraphic intervals at both sites, whereas the upper portion at both sites is a $30-40 \mathrm{~m}$ thick sequence of trona and trona-bearing muds, the production target for Tata Chemicals, our local industry partner for this drill site. The upper trona was drilled using freshwater as the drilling fluid in the initial holes because bentonite drilling mud would not mix with the high-pH brines readily available near the site. However, this strategy proved problematic because dissolution cavities formed around the borehole, undermining site stability. For boreholes $1 \mathrm{C}$ and $2 \mathrm{~A}$ drilling used only the high-pH lake brine without bentonite, which ultimately proved satisfactory because the high density of the brine was sufficient to raise the cuttings. The alternation of soft and 


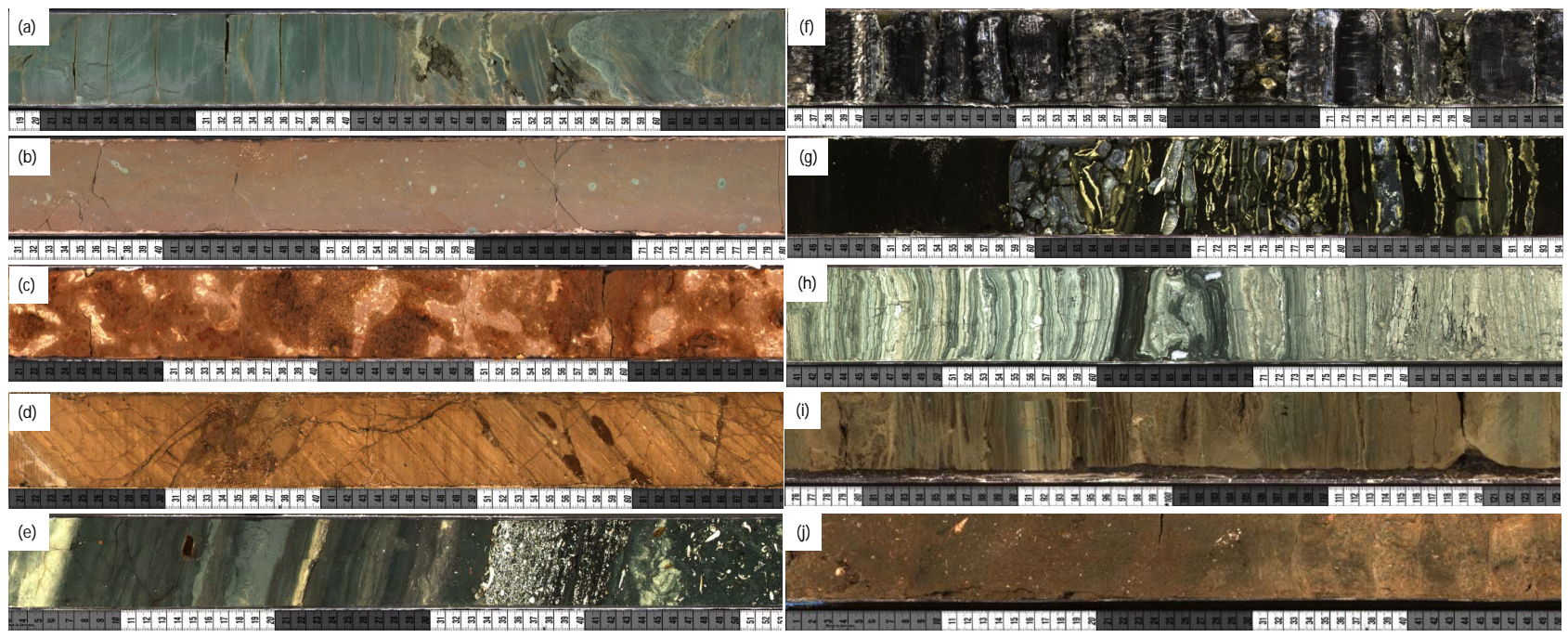

Figure 7. Representative lithologies found in HSPDP drill cores. Positions of each photo within the cores are indicated on the respective summary stratigraphy diagrams. NAO14-1B-66Q-1 (154.66-155.07 m below surface - $\mathrm{m}$ b.s.) from the Northern Awash Oso Isi site, northern Ethiopia. Note: many coring gaps in NAO14-1B are infilled by matching to the twinned borehole NAO14-1D (not illustrated), collected immediately adjacent to this core. Laminated green lake clays with soft sediment deformation. NAW14-1A-71Q-2 (138.60-139.06 m b.s.) from the Northern Awash Woranso site. Massive brown, silty, diatomaceous clay. BTB13-1A-52Q-2 (150.21-150.71 m b.s.) from the BaringoTugen Hills site, central Kenya. Well-developed paleosol with carbonate nodules. BTB13-1A-3Q-1 (9.85-10.35 m b.s.) from the BaringoTugen Hills site. Laminated diatomite with carbonate interbeds. WTK13-1A-63Q-1 (150.16-150.66 m b.s.) from the West Turkana drill site, northern Kenya. Green silty clays with mollusc coquinas. MAG14-2A-9Y-1 (19.58-20.08 m b.s.) from Lake Magadi, southern Kenya. Interbedded trona and thin muds. MAG14-1A-49Y-1 (75.02-75.52 m b.s.) Interbedded black silty clay and yellow/black chert. MAG14-2A67Y-1 (147.10-147.60 m b.s.) from Lake Magadi. Laminated muds. CHB14-2A-35A-2A (73.22-73.72 m b.s.) partly laminated green and brown muds from the Chew Bahir Basin. CHB14-2A-70Q-1A (146.58-147.05 m b.s.) brown, mollusk-bearing massive mudstones from the Chew Bahir Basin.

lithified muds and cherts (often on a sub-meter depth scale) proved a challenging coring environment. Percent core recovery at this site (in the $45-65 \%$ range) was consequently below the levels achieved at other sites. Drilling at both locations was terminated when the boreholes reached the trachytic basement rocks (at depths of $\sim 136$ and $197 \mathrm{~m}$ for Sites 1 and 2, respectively).

An exploratory shallow coring campaign was conducted at the Chew Bahir area in 2009 and 2010 along a NWSE transect from the basin margin to the center, which recovered six short sediment cores of 9-18.8 m length (Foerster et al., 2012, 2015; Trauth et al., 2015). Subsequently, a pilot drilling operation was conducted in the center of the Chew Bahir basin in March 2014 ( $41 \mathrm{~m}$ vertical borehole). Drilling at this site was terminated when flooding made the drilling site inaccessible. This was followed by the drilling of two considerably deeper, twinned vertical boreholes $(\sim 279$ and $266 \mathrm{~m}$ in flat-lying sediments for boreholes $2 \mathrm{~A}$ and $2 \mathrm{~B}$, respectively, Figs. 14, 3b) in a slightly more proximal and elevated position relative to the basin margin in NovemberDecember 2014. The CHB14-2A and 2B cores consist predominantly of reddish, brown or green silty and sandy clays, with occasional silt and calcareous sand beds. Discrete shellrich and plant debris-rich horizons occur throughout the cores. Carbonate nodule-rich muds are more common in the lower part of the core (below $\sim 90 \mathrm{~m}$ b.s.). Drilling was terminated when advancing became impractical and funds were depleted.

\section{HSPDP outreach and education activities}

The HSPDP has made a priority of developing an effective outreach and educational program that makes the project's goals and findings accessible to the broader public. Prior to and during drilling activities at each study area, an intensive effort was made to engage with the local public about our activities. This often involved having Kenyan and Ethiopian research and museum outreach specialists make presentations using visual aids such as segments of sediment cores or casts of hominin skulls to explain the science objectives and (importantly) to dispel misunderstandings concerning the nature of our drilling activities (which were commonly assumed to be for resource exploration prior to these presentations) (Fig. 3c). The HSPDP has also worked closely with the National Museums of Kenya and Ethiopia, as well as several museum institutional partners in the US, in the development of post-drilling educational resources that these museums can use in the future to explain the intersection between human evolutionary history and climate history. The most 


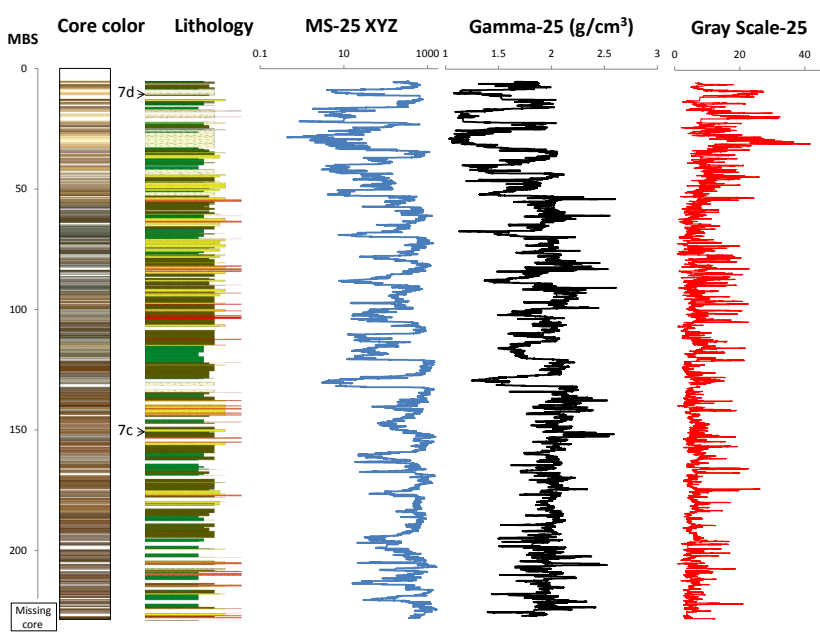

Figure 8. Summary stratigraphy of core HSPDP-BTB13-1A, from the Tugen Hills drilling area, central Kenyan Rift Valley, based on initial core description results. Columns from left to right: core color stratigraphy; lithologic log; see Fig. 5 for the key to lithologies used in all cores illustrated; composite of magnetic susceptibility (MS) log data (25-point running mean smooth) from LacCore Geotek $^{\circledR}$ XYZ point sensor data; composite of induced gamma density log data (25-point running mean smooth, spurious values $<1.0 \mathrm{gm} \mathrm{cm}^{-3}$ removed; n.b.: lower threshold used than for NA cores because of abundant dry and porous diatomites); composite of spectrophotometric grey-scale log data (25-point running mean smooth). All other data collection, instrumentation, and parameters as in Fig. 5.

visible of these efforts has the been the development of a short (14 min) 3-D film, produced by the nonprofit Earth Images Foundation (www.earthimage.org), and funded jointly by the US National Science Foundation and ICDP, which documents both the important science questions underpinning the HSPDP as well as the excitement associated with the drilling and core analysis activities (Fig. 3d). This film will be on long-term display in the human origins halls at the partner museums, and is also available in 2-D format via the project website (http://hspdp.asu.edu) and Facebook page (www.facebook.com/HSPDP). The HSPDP has a strong social media presence through its Facebook site and project website, where educational resources, such as numerous photographs of drilling and initial core description activities are made available to the general public. Another exciting and innovative HSPDP outreach activity has been the involvement of an "artist in residence", funded through our UK NERC grant. The artist, Julian Ruddock, will be using highresolution photographs and video footage including interviews he has conducted during drilling activities at the Chew Bahir site, as well as core images to create an art/science collaboration for gallery display in the UK starting in 2016 http://cargocollective.com/artscienceclimatechange/ Earth-Core-The-Hominin-Project. HSPDP members, led by co-PI Martin Trauth, are currently teaching a series of sum-

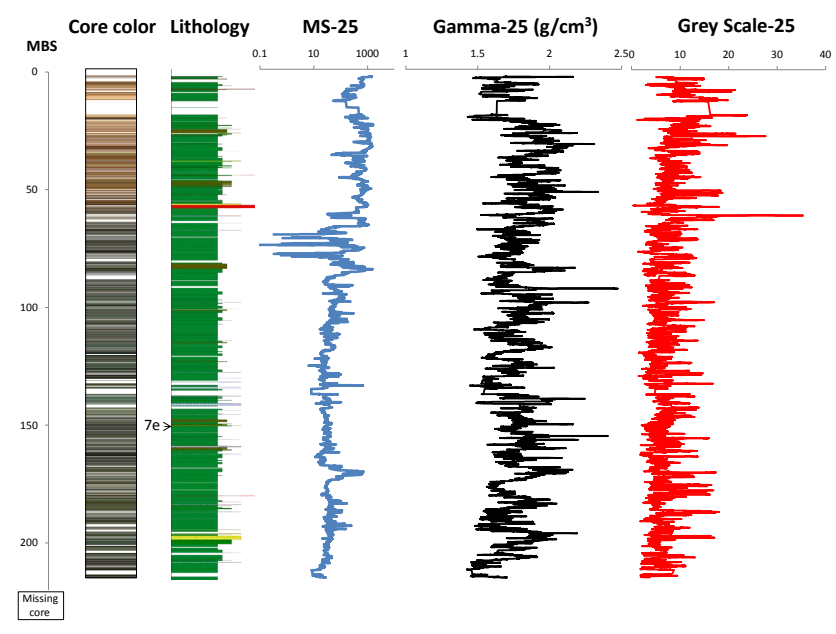

Figure 9. Summary stratigraphy of core HSPDP-WTK13-1A, from the West Turkana drilling area, northern Kenyan Rift Valley, based on initial core description results. Columns from left to right: core color stratigraphy; lithologic log; see Fig. 5 for the key to lithologies used in all cores illustrated; composite of magnetic susceptibility (MS) log data (25-point running mean smooth) from LacCore Geotek $^{\circledR}$ XYZ point sensor data; composite of induced gamma density log data (25-point running mean smooth, spurious values < $1.4 \mathrm{gm} \mathrm{cm}^{-3}$ removed); and composite of spectrophotometric grey-scale log data (25-point running mean smooth). All data collection, instrumentation and parameters as in Fig. 5.

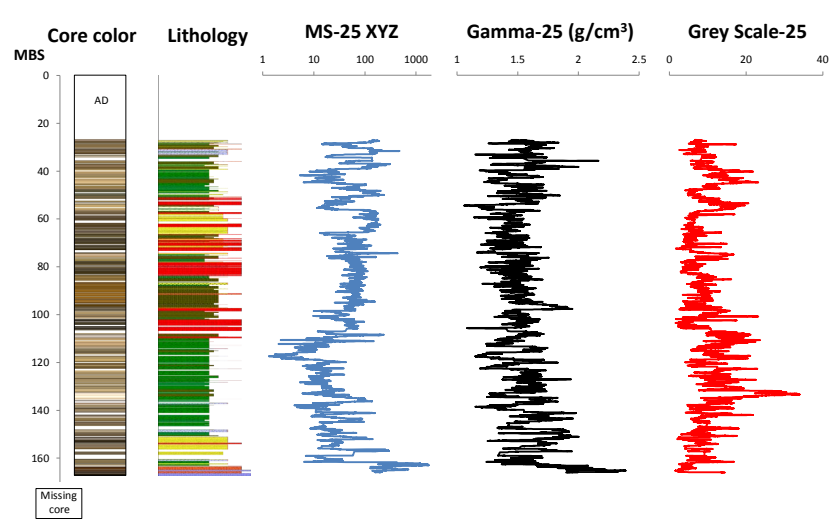

Figure 10. Summary stratigraphy of core ODP-OLO12-1A, from the Koora Plain/Olorgesailie drilling area, southern Kenyan Rift Valley, based on initial core description results. Columns from left to right: core color stratigraphy; lithologic log; see Fig. 5 for the key to lithologies used in all cores illustrated; composite of magnetic susceptibility (MS) log data (25-point running mean smooth) from LacCore Geotek $^{\circledR}$ XYZ point sensor data; composite of induced gamma density log data (25-point running mean smooth, spurious values $<1.0 \mathrm{gm} \mathrm{cm}^{-3}$ removed); and composite of spectrophotometric grey-scale log data (25-point running mean smooth). AD: auger drilled sediment samples were bagged and collected in $1 \mathrm{~m}$ intervals. All other data collection, instrumentation, and parameters as in Fig. 5. 


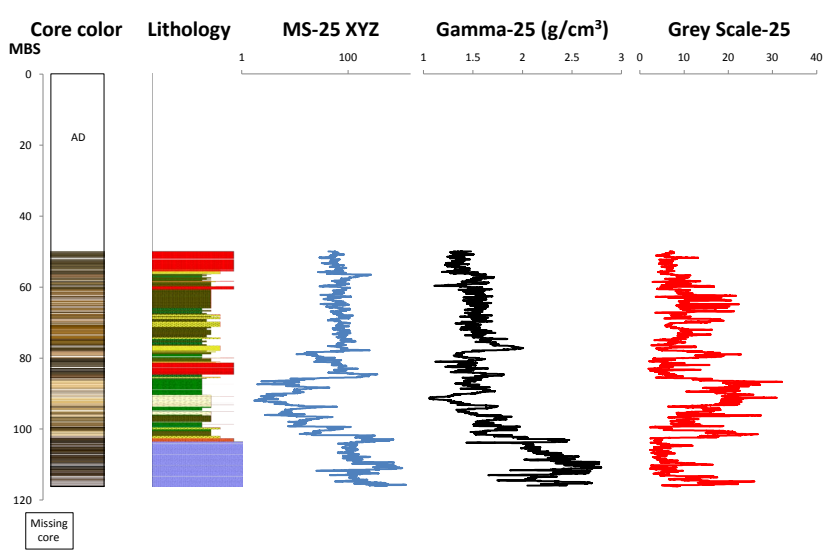

Figure 11. Summary stratigraphy of core ODP-OLO12-3A, from the Koora Plain/Olorgesailie drilling area, southern Kenyan Rift Valley, based on initial core description results. Columns from left to right: core color stratigraphy; lithologic log; see Fig. 5 for the key to lithologies used in all cores illustrated; composite of magnetic susceptibility (MS) log data (25-point running mean smooth) from LacCore Geotek ${ }^{\circledR}$ XYZ point sensor data; composite of induced gamma density log data (25-point running mean smooth, spurious values $<1.0 \mathrm{gm} \mathrm{cm}^{-3}$ removed); composite of spectrophotometric grey-scale log data (25-point running mean smooth). AD: augered drilled interval: sediment bagged and collected at Site 1, and not collected at Site 3. All other data collection, instrumentation, and parameters as in Fig. 5.

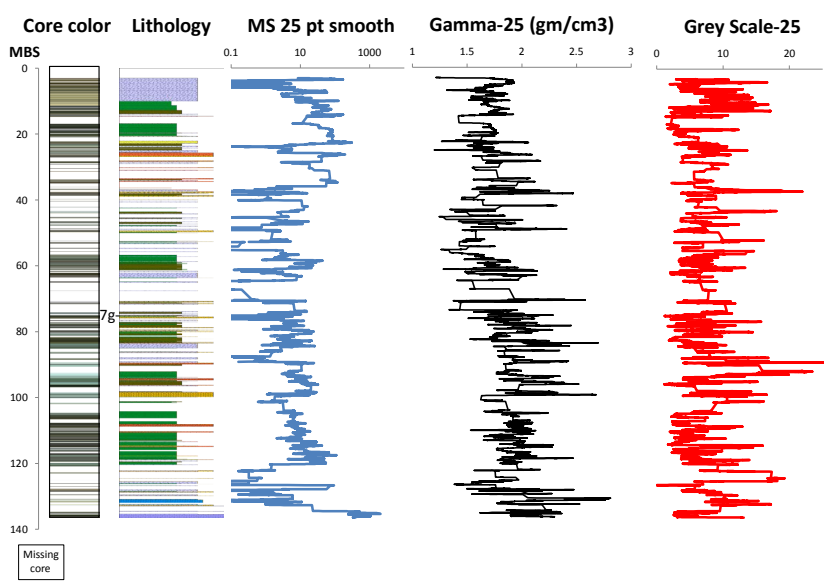

Figure 12. Summary stratigraphy of composite core HSPDPMAG14-1A + 1C (basal portion of 1C core below $125 \mathrm{~m}$ only), from the Lake Magadi drilling area, southern Kenyan Rift Valley, based on initial core description results. Columns from left to right: core color stratigraphy; lithologic log; see Fig. 5 for the key to lithologies used in all cores illustrated; composite of magnetic susceptibility (MS) log data (25-point running mean smooth) from LacCore Geotek ${ }^{\circledR}$ XYZ point sensor data; composite of induced gamma density log data (25-point running mean smooth, spurious values $<1.2 \mathrm{gm} \mathrm{cm}^{-3}$ removed); composite of spectrophotometric grey-scale log data (25-point running mean smooth). All data collection, instrumentation, and parameters as in Fig. 5.

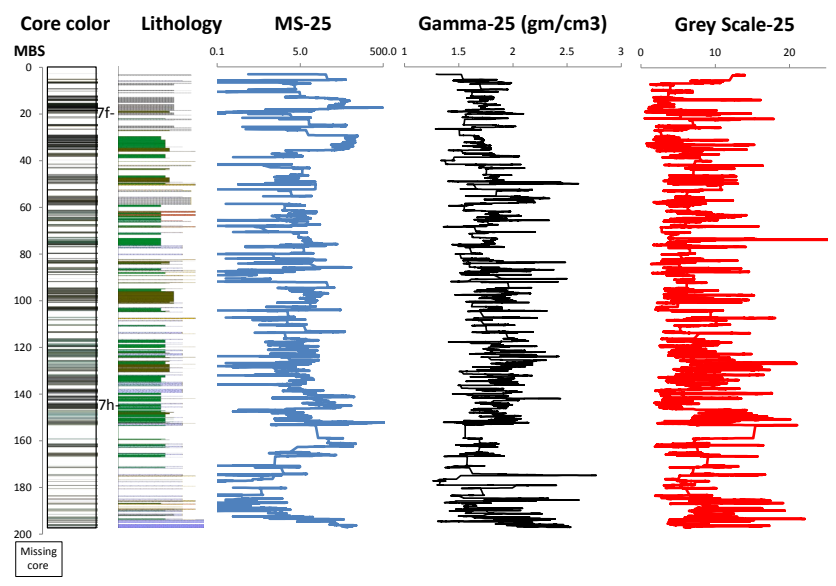

Figure 13. Summary stratigraphy of core HSPDP-MAG14-2A, from the Lake Magadi drilling area, southern Kenyan Rift Valley, based on initial core description results. Columns from left to right: core color stratigraphy; lithologic log; see Fig. 5 for the key to lithologies used in all cores illustrated; composite of magnetic susceptibility (MS) log data (25-point running mean smooth) from LacCore Geotek ${ }^{\circledR}$ XYZ point sensor data; composite of induced gamma density log data (25-point running mean smooth, spurious values $<1.2 \mathrm{gm} \mathrm{cm}^{-3}$ removed); composite of spectrophotometric grey-scale log data (25-point running mean smooth). All data collection, instrumentation, and parameters as in Fig. 5.

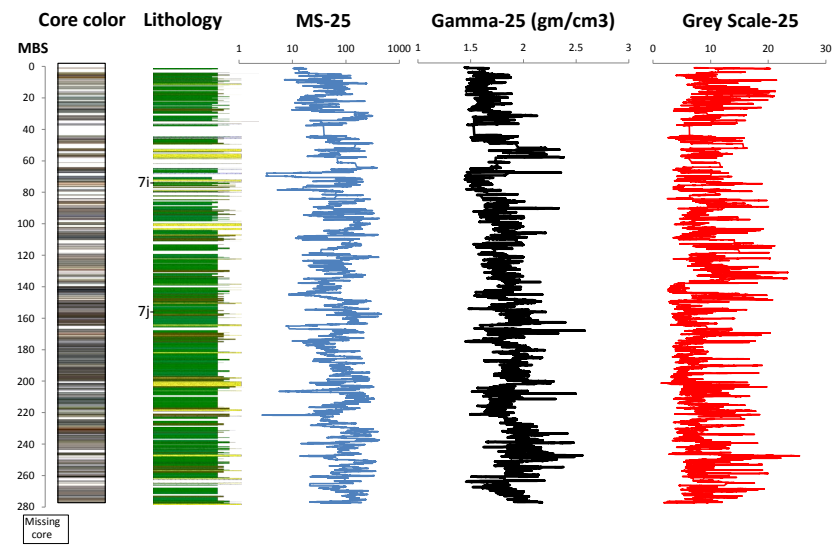

Figure 14. Summary stratigraphy of core HSPDP-CHB14-2A, from the Chew Bahir drilling area, southern Ethiopian Rift Valley, based on Initial Core Description results. Note: coring gaps in CHB14-2A are almost entirely infilled by matching to the twinned borehole CHB14-2B (not illustrated), collected immediately adjacent to this core. Columns from left to right: Core color stratigraphy; lithologic log; see Fig. 5 for the key to lithologies used in all cores illustrated; composite of magnetic susceptibility (MS) log data (25-point running mean smooth) from LacCore Geotek ${ }^{\circledR}$ XYZ point sensor data; composite of induced gamma density log data (25-point running mean smooth, spurious values $<1.4 \mathrm{gm} \mathrm{cm}^{-3}$ removed); composite of spectrophotometric grey-scale log data (25point running mean smooth). All data collection, instrumentation, and parameters as in Fig. 5. 
mer schools in the bio-geosciences that help twenty young scientists from African and European universities to design new research projects on these topics, using the latest methods of data analysis, and to present the results from these projects in an attractive and professional manner. The overall topic of the summer school, held in Ethiopia (SeptemberOctober 2015) and Kenya (February-March 2016), is tectonics, climate, and human evolution, using the latest results from the HSPDP as the basis of discussions during the event.

\section{Future plans}

Now that all HSPDP-related drilling is completed, all cores are being analyzed for a wide variety of geochronological, geochemical, sedimentological and paleoecological studies, to assemble a high-resolution record of environmental change at each of the study sites. The geochronology of the cores is being assembled through a combination of highprecision Ar/Ar, paleomagnetics, U-series, tephrostratigraphy, luminescence and (for the most recent parts of the cores ${ }^{14} \mathrm{C}$ dating. State-of-the-art organic geochemical and clumped isotope proxies of paleotemperature and paleoprecipitation are being applied to the cores. The wide array of fossils (diatoms, ostracodes, molluscs, fish, pollen, phytoliths and charcoal) are also being exploited for the information they provide about both lake and watershed paleoecological conditions. Scanning XRF, XRD, and MSCL log records are also providing extremely high-resolution records of paleoenvironmental and provenance history at each site. Another important component of this analysis is the integration of core data with nearby outcrop information about paleoenvironments of hominins and other fossils and stone tools. Extensive interaction between the data collection and modeling teams of the HSPDP is also underway, to ensure that plausible explanations of climate and landscape dynamics are developed and tested against the core and outcrop data. U1timately, through interaction between the core analysts and paleoanthropologists involved in the HSPDP, we hope to use our new high-resolution core data and climate/landscape models to both re-evaluate existing models linking hominin evolution with climate and propose new ones consistent with the vast new data set assembled by the HSPDP.

Acknowledgements. Funding for the HSPDP has been provided by ICDP, NSF (grants EAR-1123942, BCS-1241859, and EAR1338553), NERC (grant NE/K014560/1), DFG priority program SPP 1006, DFG-CRC-806 "Our way to Europe", the University of Cologne (Germany), the Hong Kong Research Grants Council (grant no. HKBU201912), the Peter Buck Fund for Human Origins Research (Smithsonian), the William H. Donner Foundation, the Ruth and Vernon Taylor Foundation, Whitney and Betty MacMillan, and the Smithsonian's Human Origins Program. We are grateful to the following organizations and individuals for all of their assistance prior to, during and following drilling in making this effort a success: the National Museums of Kenya and Ethiopia, the ARCCH (Ministry of Culture and Tourism) and Geological Survey of Ethiopia (Ministry of Mines) for facilitating permits to drill on the Afar and Chew Bahir sites, the Kenyan National Council for Science and Technology and Kenyan Ministry of Mines for providing research and export permits for the Kenyan drilling, the National Environmental Management Authority of Kenya for providing environmental permits for drilling in Kenya, DOSECC Exploration Services for drilling supervision, the Operational Support Group of ICDP for providing downhole logging services, the US National Lacustrine Core Facility (LacCore), the National Oil Company of Kenya, Tullow Oil, Tata Magadi, the Magadi, Turkana and Baringo County Councils, the Afar and Southern Nations Regional State Governments for facilitating access to the drill sites, Oldoinyo Nyokie Group Ranch, Soi Lodge, the Nariokotome Mission and people of Nariokotome, Drilling and Prospecting International Ltd., Geosearch (now Orezone) Ltd., Ardan Logistics, Ethioder Ltd., and Boniface Kimeu, Francis Ekai, Mesfin Mekonnen, and Brian Grivna. We thank two anonymous reviewers for many helpful suggestions. This is publication number 6 of the Hominin Sites and Paleolakes Drilling Project.

Edited by: U. Harms

Reviewed by: two anonymous referees

\section{References}

Alemseged, Z.: An integrated approach to taphonomy and faunal change in the Shungura Formation (Ethiopia) and its implication for hominind evolution, J. Hum. Evol., 44, 451-478, 2003.

Alemseged, Z., Spoor, F., Kimbel, W. H., Bobe, R., Geraads, E., Reed, D., and Wynn, J. G.: A juvenile early hominin skeleton from Dikika, Ethiopia, Nature, 443, 296-301, 2006.

Armitage, S. J., Jasmin, S. A., Marks, A. E., Parker, A. G., Usik, V. I., and Uerpmann, H. P.: The Southern Route "Out of Africa": Evidence for an Early Expansion of Modern Humans into Arabia, Science, 331, 453-456, 2011.

Bailey, G. N., Reynolds, S. C., and King, G. C.: Landscapes of human evolution: models and methods of tectonic geomorphology and the reconstruction of hominin landscapes, J. Hum. Evol., 60, 257-280, doi:10.1016/j.jhevol.2010.01.004, 2011.

Baker, B. H.: Geology of the Magadi area, Rep. Geol. Surv. Kenya, 42, 1958.

Behrensmeyer, A. K., Todd, N. E., Potts, R., and McBrinn, G.: Late Pliocene faunal turnover in the Turkana Basin, Kenya and Ethiopia, Science, 278, 1589-1594, 1997.

Behrensmeyer, A. K., Potts, R., Deino, A., and Ditchfield, P.: Olorgesailie, Kenya: A million years in the life of a rift basin, edited by: Renaut, R. W. and Ashley, G. M., in: Sedimentation in Continental Rifts, SEPM Spec. Publ., 73, 97-106, 2002.

Blome, M. W., Cohen, A. S., Tryon, C. A., Brooks, A. S., and Russell, J.: The environmental context for the origins of modern human diversity: A synthesis of regional variability in African climate 150,000-30,000 years ago, J. Hum. Evol., 62, 563-592, doi:10.1016/j.jhevol.2012.01.011, 2012.

Bobe, R. and Behrensmeyer, A. K.: The expansion of grassland ecosystems in Africa in relation to mammalian evolution and the origin of the genus Homo, Palaeogeogr. Palaeoclim., 207, 399420, 2004. 
Bobe, R., Behrensmeyer, A. K., Eck, G. G., and Harris, J. M.: Patterns of abundance and diversity in late Cenozoic bovids from the Turkana and Hadar Basins, Kenya and Ethiopia, in: Hominin Environments in the East African Pliocene: An Assessment of the Faunal Evidence, edited by: Bobe, R., Alemseged, Z., and Behrensmeyer, A. K., Springer, 129-157, 2007.

Bonnefille, R., Potts, R., Chalié, F., Jolly, D., and Peyron, O.: High-resolution vegetation and climate change associated with Pliocene Australopithecus afarensis, P. Natl. Acad. Sci. USA, 101, 12125-12129, 2004.

Brown, F. H., Haileab, B., and McDougall, I.: Sequence of tuffs between the KBS Tuff and the Chari Tuff in the Turkana Basin, Kenya and Ethiopia, J. Geol. Soc. Lond., 163, 185-204, 2006.

Campisano, C. J. and Feibel, C. S.: Connecting local environmental sequences to global climate patterns: Evidence from the hominin-bearing Hadar Formation, Ethiopia, J. Hum. Evol., 53, 515-527, 2007.

Cane, M. A. and Molnar, P.: Closing of the Indonesia seaway as a precursor to east African aridification around 3-4 million years ago, Nature, 411, 157-162, 2001.

Cerling, T. E., Wynn, J. G., Andanje, S. A., Bird, M. I., Koriri, D. K., Levin, N. E., Mace, W., Macharia, A., Quade, J., and Remien, C. H.: Woody cover and hominin environments in the past 6 million years, Nature, 476, 51-56, 2011.

Chapman, G. R. and Brook, M.: Chronostratigraphy of the Baringo Basin, Kenya, in: Geological background to fossil man, edited by: Bishop, W. W., Scottish Academic Press, London, 207-223, 1978.

Cohen, A., Arrowsmith, R., Behrensmeyer, A. K., Campisano, C., Feibel, C., Fisseha, S., Johnson, R., Kubsa Bedaso, Z., Lockwoodt, C., Mbua, R., Olago, D., Potts, R., Reed, K., Renaut, R., Tiercelin, J.-J., and Umer, M.: Understanding Paleoclimate and Human Evolution Through the Hominin Sites and Paleolakes Drilling Project, Sci. Dril., 8, 60-65, doi:10.5194/sd-8-60-2009, 2009.

Cohen, A. S. and Umer, M.: Connecting Scientific Drilling and $\mathrm{Hu}-$ man Evolution, EOS, 90, p. 122, 2009.

Cohen, A. S., Lezzar, K. E., Cole, J., Dettman, D., Ellis, G. S., Eagle, M., Plisnier, P. D., Langenberg, V., Blaauw, M., and Zilifi, D.: Late Holocene linkages between decade-century scale climate variability and productivity at Lake Tanganyika, Africa, J. Paleolimnol., 36, 189-209, doi:10.1007/s10933-006-9004-y, 2006.

Cohen, A. S., Stone, J. R., Beuning, K. R., Park, L. E., Reinthal, P. N., Dettman, D., Scholz, C. A., Johnson, T. C., King, J. W., Talbot, M. R., Brown, E. T., and Ivory, S. J.: Ecological Consequences of Early Late-Pleistocene Megadroughts in Tropical Africa, P. Natl. Acad. Sci. USA, 104, 16422-16427, 2007.

Crossley, R.: The Cenozoic stratigraphy and structure of the western part of the rift valley in southern Kenya, J. Geol. Soc. Lond., 136, 393-405, 1979.

Day, M. H.: Early Homo sapiens remains from the Omo River region of southwest Ethiopia: Omo human skeletal remains, Nature, 222, 1135-1138, 1969.

Deino, A. L., Kingston, J. D., Glen, J. M., Edgar, R. K., and Hill, A.: Precessional Forcing of Lacustrine Sedimentation in the late Cenozoic Chemeron Basin, Central Kenya Rift, Earth Planet. Sc. Lett., 247, 41-60, 2006.
deMenocal, P.: Plio-Pleistocene African climate, Science, 270, 5359, 1995.

deMenocal, P.: African climate change and faunal evolution during the Plio-Pleistocene, Earth Planet Sc. Lett., 220, 3-24, 2004.

Eugster, H. P.: Lake Magadi, Kenya and its precursors, in: Hypersaline Brines and Evaporites Elsevier, edited by: Nissenbaum, A., Amsterdam, 195-232, 1980.

Federov, A. V., Brierley, C. M., Lawrence, K. T., Liu, Z., Dekens, P. S., and Ravelo, A. C.: Patterns and mechanisms of earl Pliocene warmth, Nature, 496, 43-49, 2013.

Foerster, V., Junginger, A., Langkamp, O., Gebru, T., Asrat, A., Umer, M., Lamb, H., Wennrich, V., Rethemeyer, J., Nowaczyk, N., Trauth, M. H., and Schäbitz, F.: Climatic change recorded in the sediments of the Chew Bahir basin, southern Ethiopia, during the last 45,000 years, Quaternary Int., Special Issue Vol. 274, 25-37, doi:10.1016/j.quaint.2012.06.028, 2012.

Foerster, V., Vogelsang, R., Junginger, A., Asrat, A., Lamb, H. F., Schaebitz, F., and Trauth, M. H.: Environmental Change and Human Occupation of Southern Ethiopia and Northern Kenya during the last 20,000 years, Quaternary Sci. Rev., 129, 333-340, doi:10.1016/j.quascirev.2015.10.026, 2015.

Feibel, C. S.: A Geological History of the Turkana Basin, Evol. Anthropol., 20, 206-216, 2011.

Geraads, D., Bobe, R., and Reed, K.: Pliocene Bovidae (Mammalia) from the Hadar Formation of Hadar and Ledi-Geraru, Lower Awash, Ethiopia, J. Vertebr. Paleontol., 32, 180-197, 2012.

Harmand, S., Lewis, J. E., Feibel, C. S., Lepre, C., Prat, S., Lenoble, A., Boes, X., Quinn, R., Arroyo, A., Clement, S., Daver, G., Brugal, J. P., Leakey, L., Mortlock, R. A., Wright, J. D., Lokorodi, S., Kirwa, C., Kent, D. V., and Roche, H.: 3.3 million year old stone tools from Lomekwi 3, West Turkana, Kenya, Nature, 521, 310-315, doi:10.1038/nature14464, 2015.

Harris, J. M., Brown, F. H., and Leakey, M. G.: Geology and paleontology of Plio-Pleistocene localities west of Lake Turkana, Kenya, Contributions in Science, 399, 1-128, 1988.

Johanson, D. C., Taieb, M., and Coppens, Y.: Pliocene hominids from the Hadar Formation, Ethiopia (1973-1977): Stratigraphic, chronological and paleoenvironmental contexts, with notes on hominid morphology and systematics, Amer. Jour. Phys. Anthro., 57, 373-402, 1982.

Jones, B. F., Eugster, H. P., and Rettig, S. L.: Hydrochemistry of the Lake Magadi Basin, Kenya, Geochim. Cosmochim. Ac., 41, 53-72, 1977.

Joordens, J. C. A., Vonhof, H. B., Feibel, C. S., Lourens, L. J., Dupont-Nivet, G., van der Lubbe, J. H. J. L., Sier, M. J., Davies, G. R., and Kroon, D.: An astronomically-tuned climate framework for hominins in the Turkana Basin, Earth Planet. Sc., 307, 1-8, 2011.

Kimbel, W. H., Rak, Y., and Johanson, D. C.: The Skull of Australopithecus afarensis, Oxford University Press, New York, 2004.

Kingston, J. D., Deino, A., Hill, A., and Edgar, R.: Astronomically forced climate change in the Kenyan Rift Valley 2.7-2.55 Ma: Implications for the evolution of early hominin ecosystems, J. Hum. Evol., 53, 487-503, 2007.

Kuper, R. and Kröpelin, S.: Climate-Controlled Holocene Occupation in the Sahara: Motor of Africa's Evolution, Science, 313, 803-807, 2006. 
Larrasoaña, J. C., Roberts, A. P., Rohling, E. J., Winklhofer, M., and Wehausen, R.: Three million years of monsoon variability over the northern Sahara, Clim. Dynam., 21, 689-698, 2003.

Lepre, C. J., Quinn, R. L., Joordens, J. J., Swisher, C. C., and Feibel, C. S.: Plio-Pleistocene facies environments from the KBS Member, Koobi Fora Formation: implications or climate controls on the development of lake-margin hominin habitats in the northeast Turkana Basin (northwest Kenya), J. Hum. Evol., 53, 504-514, 2007.

Lepre, C. J., Roche, H., Kent, D. V., Harmand, S., Quinn, R., Brugal, J.-P., Texier, P.-J., Lenoble, A., and Feibel, C. S.: An earlier origin for the Acheulian, Nature, 477, 82-85, 2011.

Maslin, M. A., Brierley, C., Milner, A. M., and Schultz, S.: East African climate pulses and early human evolution, Quaternary. Sc. Rev., 101, 1-17, 2014.

McDougall, I., Brown, F. H., and Fleagle, J. G.: Stratigraphic placement and age of modern humans from Kibish, Ethiopia, Nature, 433, 733-736, 2005.

McDougall, I., Brown, F. H., Vasconcelos, P. M., Cohen, B. E., Thiede, D. S., and Buchanan, M. J.: New single crystal 40Ar/39Ar ages improve time scale for deposition of the Omo Group, Omo-Turkana Basin, East Africa, J. Geol. Soc., London, 169, 213-226, 2012.

McPherron, S. P., Alemseged, Z., Marean, C. W., Wynn, J. G., Reed, D., Geraads, D., Bobe, R., and Béarat, H. A.: Evidence for stonetool-assisted consumption of animal tissues before 3.39 million years ago at Dikika, Ethiopia, Nature, 466, 857-860, 2010.

Mellars, P.: Why did modern human populations disperse from Africa ca 60,000 years ago? A new model, P. Natl. Acad. Sci. USA, 103, 9381-9386, 2006.

Molnar, P. and Cane, M. A.: Early Pliocene (pre-Ice Age) El Niñolike climate: Which El Niño?, Geosphere, 3, 337-365, 2007.

Owen, R. B., Potts, R., Behrensmeyer, A. K., and Ditchfield, P.: Diatomaceous sediments and environmental change in the Pleistocene Olorgesailie Formation, southern Kenya Rift Valley, Palaeogeogr. Palaeoclim., 269, 17-37, 2008.

Owen, R. B., Renaut, R. W., Scott, J. J., Potts, R., and Behrensmeyer, A. K.: Wetland sedimentation and associated diatoms in the Pleistocene Olorgesailie Basin, southern Kenya Rift Valley, Sediment. Geol., 222, 124-137, 2009a.

Owen, R. B., Potts, R., and Behrensmeyer, A. K.: Reply to the comment on "Diatomaceous sediments and environmental change in the Pleistocene Olorgesailie Formation, southern Kenya Rift Valley", Palaeogeogr. Palaeoclim., 282, 147-148, 2009b.

Pilskaln, C. and Johnson, T. C.: Seasonal signals in Lake Malawi sediments, Limnol. Oceanogr., 36, 544-557, 1991.

Potts, R.: Evolution and climate variability, Science, 273, 922-923, 1996.

Potts, R. and Faith, J. T.: Alternating high and low climate variability: the context of natural selection and speciation in PlioPleistocene hominin evolution, J. Hum. Evol., 87, 5-20, 2015.

Potts, R., Behrensmeyer, A. K., and Ditchfield, P.: Paleolandscape variation in early Pleistocene hominid activities: Members 1 and 7, Olorgesailie Formation, Kenya, J. Hum. Evol., 37, 747-788, 1999.

Reed, K. E.: Paleoecological patterns at the Hadar hominin site, Afar Regional State, Ethiopia, J. Hum. Evol., 54, 743-768, 2008.

Reed, K. E. and Rector, A. L.: African Pliocene Paleoecology: Hominin Habitats, Resources and Diets, in: Early Human Diets: The
Known, the Unknown and the Unknowable, edited by: Ungar, P., Oxford University Press, Oxford, 262-288, 2007.

Roche, H., Brugal, J.-P., Delagnes, A., Feibel, C., Harmand, S., Kibunjia, M., Prat, S., and Texier, P.-J.: Plio-Pleistocene archaeological sites in the Nachukui Formation, West Turkana, Kenya: synthetic results 1997-2001, C. R. Palevol, 2, 663-673, 2004.

Scholz, C. A., Johnson, T. C., Cohen, A. S., King, J. W., Peck, J., Overpeck, J. T., Talbot, M. R., Brown, E. T., Kalindekafe, L., Amoako, P., Lyons, R. P., Shanahan, T. M., Castaneda, I. S., Heil, C. W., Forman, S. L., McHargue, L. R., Beuning, K. R., Gomez, J., and Pierson, J.: East African megadroughts between 135-75 kyr ago and implications for early human history, P. Natl. Acad. Sci. USA, 104, 16416-16421, 2007.

Scholz, C. A., Cohen, A. S., Johnson, T. C., King, J., Talbot, M. R., and Brown, E. T.: Scientific drilling in the Great Rift Valley: The 2005 Lake Malawi Scientific Drilling Project-An overview of the past 145,000 years off climate variability in Southern Hemisphere East Africa, Palaeogeogr. Palaeoclim., 303, 3-19, 2011.

Sepulchre, P., Ramstein, G., Fluteau, F., Schuster, M., Tiercelin, J. J., and Brunet, M.: Tectonic uplift and Eastern Africa aridification, Science, 313, 1419-1423, 2006.

Sikes, N. E., Potts, R., and Behrensmeyer, A. K.: Early Pleistocene habitat in Member 1 Olorgesailie based on paleosol stable isotopes, J. Hum. Evol., 37, 721-746, 1999.

Surdam, R. C. and Eugster, H. P.: Mineral reactions in the sedimentary deposits of the Lake Magadi region, Kenya, Bull. Geol. Soc. Am., 87, 1739-1752, 1976.

Suwa, G., Nakaya, H., Asfaw, B., Saegusa, H., Amyaze, A., Kono, R., Beyene, Y., and Katoh, S.: Plio-Pleistocene terrestrial mammal assemblage from Konso, Southern Ethiopia, J. Vert. Paleo, 23, 901-916, 2003.

Trauth, M. H. and Maslin, M. A.: Comment on "Diatomaceous sediments and environmental change in the Pleistocene Olorgesailie Formation, southern Kenya Rift Valley" by R.B. Owen, R. Potts, A.K. Behrensmeyer and P. Ditchfield [Palaeogeography, Palaeoclimatology, Palaeoecology 269 (2008) 17-37], Palaeogeogr. Palaeocl., 282, 145-146, 2009.

Trauth, M. H., Maslin, M. A., Deino, A., and Strecker, M. R.: Late Cenozoic moisture history of East Africa, Science, 309, 20512053, 2005.

Trauth, M. H., Larrasoaña, J. C., and Mudelsee, M.: Trends, rhythms and events in Plio-Pleistocene African climate, Quaternary Sci. Rev., 28, 399-411, 2009.

Trauth, M. H., Bergner, A. G. N., Foerster, V., Junginger, A., Maslin, M. A., and Schaebitz, F.: Episodes of Environmental Stability and Instability in Late Cenozoic Lake Records of Eastern Africa, J. Hum. Evol., 87, 21-31, 2015.

Vrba, E. S.: Ecological and adaptive changes associated with early hominid evolution, in: Ancestors: The Hard Evidence, edited by: Delson, E., Alan R Liss, New York, 63-71, 1985.

Vrba, E. S.: Late Pliocene Climatic Events and Hominid Evolution, in: The Evolutionary History of the Robust Australopithecines Aldine de Gruyter, edited by: Grine, F., New York, 405-426, 1988.

Vrba, E. S.: The fossil record of African antelopes (Mammalia, Bovidae) in relation to human evolution and paleoclimate, in: $\mathrm{Pa}-$ leoclimate and Human Evolution, with Emphasis on Human Origins, edited by: Vrba, E. S., Yale University Press, New Haven, 385-411, 1995. 
Wichura, H., Bousquet, R., Oberhansli, R., Strecker, M., and Trauth, M. H.: Evidence for middle Miocene uplift of the East African Plateau, Geology, 38, 543-546, 2010.
Wilson, K. E., Maslin, M. A., Leng, M. J., Kingston, J. D., Deino, A. L., Edgar, R. K., and Mackay, A. W.: East African lake evidence for Pliocene millennial-scale climate variability, Geology, 42, 955-958, 2014. 